\title{
PEMURNIAN INTEGRITAS: \\ Penelitian Puitis Mazmur 26
}

\author{
Armand Barus*
}

\begin{abstract}
Abstrak: Pembacaan Mazmur 26 dengan menggunakan metode penelitian puitis (poetic criticism) menghasilkan makna berbeda dengan metode penafsiran yang digunakan penafsir sebelumnya. Melalui penelitian puitis terungkap pesan bahwa sentral Mazmur 26 adalah proses pemurnian orang benar yang justru terjadi melalui dan di dalam kehadirannya di tengah-tengah orang fasik.
\end{abstract}

Abstract: Reading Psalm 26 with poetic criticism results in getting a from different meaning the interpretation method used by previous interpreters. Using poetic criticism in reading Psalm 26 reveals that the central message of Psalm 26 is purification of the righteous which precisely happens in and through his or her presence amongs the wicked.

Kata-kata Kunci: Mazmur ratapan, penelitian puitis, keluhan, perasaan, pengenalan akan Allah, perubahan suasana teks (mood), integritas.

\section{Pendahuluan}

"Saya harus resign (berhenti) dari pekerjaan".

"Mengapa harus resign? Ada masalah apa?"

"Kantor itu penuh suap, bayangkan penyuap dan yang disuap berkumpul di satu tempat!"

* Penulis adalah dosen Biblika di Sekolah Tinggi Teologi Amanat Agung. Penulis dapat dihubungi melalui email: armand_barus@sttaa.ac.id. 
Anda setuju ia berhenti dari pekerjaannya dan mencari pekerjaan lain? Apa nasihat Anda kepadanya? Bila Saudara mempunyai teman yang sedang menghadapi persoalan seperti dinyatakan di atas, apa nasihat Saudara kepadanya? Mengundurkan diri atau tetap bertahan?

Mazmur 26 menggambarkan keadaan yang mirip dengan dialog di atas. Pemazmur berada di tengah lingkungan orang fasik. Relasi pemazmur sehari-hari dengan orang fasik menciptakan persoalan ke dalam hidup pemazmur. Di tengah-tengah hidup bersama orang fasik integritas pemazmur mendapat ujian. Bagaimana pemazmur menyelesaikan masalahnya? Pemazmur pergi mengasingkan diri di gunung? Atau pemazmur berupaya membinasakan semua orang fasik? Apa yang harus dilakukannya?

Melalui penelitian puitis terhadap Mazmur 26 terungkap pesan tentang integritas pemazmur yang mengalami pemurnian melalui dan di dalam relasi dengan orang fasik. Penelitian puitis (poetic criticism) memperhatikan dengan serius keluhan pemazmur, perasaan pemazmur yang timbul akibat keluhannya, pengenalan pemazmur akan Allah di dalam dan melalui penderitaannya, perubahan suasana teks (mood) sebagai cerminan ratapan dan pujian ketika pemazmur mengalami penderitaan. ${ }^{1}$ Hasilnya? Suatu pembacaan yang lebih segar terhadap Mazmur 26.

1. Contoh-contoh lihat Armand Barus, Mengenal Tuhan Melalui Penderitaan (Jakarta: Scripture Union Indonesia, 2016), 73-152. 


\section{Keluhan}

Hidup di tengah orang fasik (ay. 4, 5)

Apa sebenarnya keluhan pemazmur? Pendapat para penafsir terhadap Mazmur 26 dapat dikelompokkan ke dalam dua golongan.

Pertama, pemazmur sedang mengalami masalah. Namun, para penafsir berbeda pendapat mengenai keluhan pemazmur. Apa saja keluhan pemazmur? Pemazmur sedang menderita penyakit (Gunkel) ${ }^{2}$ atau sedang menghadapi "an unwarranted accusation" atau "false accusations" (Artur Weiser, Robert Davidson, A.A. Anderson, Mitchell Dahood, F. Villanueva). ${ }^{3}$ Artur Weiser, misalnya, mendasarkan tafsirannya pada 1 Raja-raja 8:31-32. Teks ini dianggap Weiser sebagai latar belakang Mazmur 26. Lengkapnya Weiser menulis "In the face of an unwarranted accusation the worshipper seeks to attain his vindication by means of an ordeal in the Temple (vv. 1-3), where he submits to the ritual ceremony of purification ( $v$. 6) after he had taken an oath of purification (vv. 3-5); he prays (vv. 9-

2. Dikutip A.A. Anderson, The Book of Psalms: Psalms 1-72, vol. 1, New Century Bible Commentary (Grand Rapids: Eerdmans, 1972), 213.

3. Artur Weiser, The Psalms: A Commentary, The Old Testament Library (Philadelphia: Westminster, 1962), 242; Robert Davidson, The Vitality of Worship: A Commentary on the Book of Psalms (Grand Rapids: Eerdmans, 1998), 93; Anderson, Psalms 1-72, 1: 213; Mitchell Dahood, S.J., Psalms I:1-50: Introduction, Translation, and Notes, The Anchor Yale Bible 16 (New Haven: Yale University, 1965), 161, lebih spesifik menulis bahwa pemazmur "accused of idol-worship". Federico G. Villanueva, Psalms 1-72: A Pastoral and Contextual Commentary, Asia Bible Commentary Series (Carlisle: Langham Global Library, 2016), 157. 
10) for his preservation from dying 'with sinners and bloodthirsty men.'"14

Namun, pembacaan teliti memperlihatkan tiadanya penyebutan penyakit atau kesembuhan dari sakit atau tuduhan apalagi fitnah yang ditujukan terhadap pemazmur. Craigie tepat mengamati dalam Mazmur 26 "there is no explicit reference to sickness or any other situation of distress, nor are false accusers or accusations against the psalmist specified." ${ }^{5}$ Oleh karena itu pandangan pertama ini tidak dapat dipertahankan.

Kedua, sesungguhnya tidak ada masalah pemazmur (Peter Craigie, John Goldingay, Tremper Longman). Peter Craigie, mengikut Vogt (1962), memandang pemazmur sedang mempersiapkan diri memasuki bait Allah dengan memakai Mazmur 26. Mazmur 26 adalah mazmur persiapan untuk masuk ke dalam bait Allah di Yerusalem. Craigie menulis bahwa Mazmur 26 " in its original form and setting as part of an entrance liturgy utilized in a ritual at the temple prior to participation in worship.." ${ }^{6}$ Di lain pihak Goldingay mengamati bahwa Mazmur 26 "lacks any lament or the urgency that suggests a current crisis in the suppliant's life, and rather suggests a

4. Weiser, Psalms, 242.

5. Peter C. Craigie, Psalms 1-50, Word Biblical Commentary 19 (Dallas: Word Books, 1983), 224.

6. Craigie, Psalms 1-50, 224. 
prayer that people could pray at any time". ${ }^{7}$ Baik Craigie maupun Goldingay mengaitkan penggunaan Mazmur 26 dengan ibadah.

Usulan-usulan tersebut di atas dipandang sebagai suatu kemungkinan oleh karena kekurangan bukti pendukungnya. Secara eksplisit pemazmur menyampaikan keluhan oleh karena ia berada dan hidup di tengah-tengah orang fasik. Namun pemazmur "tidak duduk dengan orang fasik" (ay. 4, 5). Keadaan ini menjadi sumber penderitaan pemazmur. Pemazmur tidak duduk, tidak bergaul erat dengan orang fasik. Tidak bergaul erat dengan orang fasik tidak berarti pemazmur mengasingkan dirinya dari orang fasik atau hidup tanpa kontak fisik dengan mereka. Seandainya pemazmur hidup tanpa kontak fisik dengan mereka, tentu tidak perlu pemazmur mengutarakan keluhannya. Pemazmur tidak bergaul dengan orang fasik dalam arti pemazmur tidak menipu, tidak munafik seperti yang dilakukan orang fasik. Pemazmur tidak menipu, tidak munafik karena ia hidup dalam kebenaran Tuhan dan matanya tertuju kepada kasih setia Tuhan. Ungkapan mata tertuju menggambarkan komitmen. Perjalanan hidup pemazmur terfokus dan berada di jalan kasih setia Tuhan. Komitmen terhadap kebenaran Tuhan di tengah-tengah orang fasik menciptakan masalah dalam hidup pemazmur. Ringkasnya, secara sosial pemazmur hidup di tengah-tengah orang fasik dan secara rohani pemazmur bergaul erat dan terus-menerus

7. John Goldingay, Psalms 1-41, vol. 1, Baker Commentary on the Old Testament Wisdom and Psalms (Grand Rapids: Baker Academic, 2006), 380. 
dengan Allah. Keadaan ini menjadi sumber pergumulan hidup pemazmur.

Pemazmur hidup di tengah orang fasik. Siapakah orang fasik? Kesejajaran kiastik berikut memperlihatkan siapa orang fasik yang digambarkan pemazmur.

4. Aku tidak duduk dengan penipu, dan

dengan orang munafik aku tidak bergaul;

5. aku benci kepada perkumpulan orang yang berbuat jahat, dan dengan orang fasik aku tidak duduk.

Kesejajaran kiastik di atas memperlihatkan orang fasik adalah penipu, orang munafik, orang yang berbuat jahat. Tulisan ini mengusulkan fungsi orang fasik sebagai 'api pengujian' integritas pemazmur. Bagaimana penjelasannya?

Dalam ayat 9 dan 10 lebih jauh pemazmur menggambarkan orang fasik sebagai orang berdosa, penumpah darah. Pada tangan mereka melekat perbuatan mesum dan menerima suap (ay. 9-10). Istilah perbuatan mesum (TB-LAI) merupakan terjemahan Ibrani zimmā $\bar{a}^{\mathrm{h}}$ Istilah zimmân ${ }^{\mathrm{h}}$ diterjemahkan berbeda: berbuat jahat (BIMK), wicked schemes (NIV), evil devices (RSV). Istilah zimmā ${ }^{\mathrm{h}}$ digunakan dalam beberapa nas sebagai rujukan terhadap perbuatan terkait seksualitas (Im. 18:17; 19:29; 20:14; Ayb. 31:11). Mungkin lebih tepat istilah zimma $\bar{a}^{\mathrm{h}}$ dalam ayat ini diterjemahkan 'maksud 
jahat' (Mzm. 119:150; Ams. 21:27). Mereka penumpah darah tetapi tangan mereka melekat perbuatan jahat. Bukankah sebagai penumpah darah seharusnya pada tangan mereka melekat darah? Siapakah mereka ini? Menurut Goldingay ${ }^{8}$ mereka ini adalah orangorang yang sesungguhnya bertanggung jawab atas tertumpahnya darah orang lain. Mereka menyuap orang lain untuk menumpahkan darah orang lain kemudian membelokkan keadilan dengan suap agar tidak dihukum atas perbuatannya. Sungguh jahat perbuatan mereka.

Berada di tengah-tengah kehidupan orang fasik pemazmur menegaskan bahwa ia hidup dalam 'ketulusan' (țōm). Penegasan ini ditampilkan pemazmur dengan pengulangan kata tōm pada ayat 1 dan 11. Pengulangan pada permulaan dan akhir mazmur disebut sebagai inklusio. Kata tōm diterjemahkan TB-LAI sebagai ketulusan. Mungkin terjemahan tepat adalah 'integritas', sehingga terjemahannya 'aku telah hidup dalam integritas'. ${ }^{9}$ Pemazmur hidup dalam integritas. Arti dasar integritas adalah "wholeness, usually in the sense of whole-heartedness or sincerity, rather than faultlessness". ${ }^{10}$ Anderson menambahkan bahwa integritas "is not to be judged by some ideal or absolute standard, but by one's relationship to God

8. Goldingay, Psalms 1-41., 1:386.

9. Demikian juga Davidson, Vitality of Worship, 93; Anderson, Psalms 1-72, 1:214; Goldingay, Psalms 1-41, 1:379-80.

10. Derek Kidner, Psalms 1-72: An Introduction and Commentary on Books I and II of the Psalms, The Tyndale Old Testament Commentaries (Downers Grove: IVP, 1973), 118. 
within the framework of his revelation". ${ }^{11}$ Pemazmur yang hidup dengan integritas di tengah-tengah orang fasik tentu saja menimbulkan keluhan. Dengan perkataan lain, keluhan pemazmur muncul bukan karena dosa atau penyakit atau masalah keluarga melainkan karena ia mempertahankan integritasnya.

Pemazmur hidup bersama dengan orang fasik, tetapi ia tidak menerima prinsip hidup dan nilai moral orang fasik dan menolak melakukan perbuatan fasik. Pemazmur tidak terlibat dalam penipuan dan sumpah palsu seperti terlihat melalui pernyataan 'membasuh tangan tanda tak bersalah' (ay. 6). Ungkapan tersebut berdasarkan Mazmur 24:4 menyatakan ketidakterlibatan dalam penipuan dan sumpah palsu. Ungkapan tersebut bukan rujukan suatu ritual purifikasi (Kel. 30:19-21; UI. 21:1-9), bukan ketidakterlibatan pemazmur dalam penyembahan berhala (Dahood), ${ }^{12}$ juga bukan berarti pemazmur terlibat dalam penumpahan darah (Goldingay). ${ }^{13}$ Pemazmur tidak menipu dan tidak bersumpah serapah. Sebaliknya pemazmur berjalan mengelilingi mezbah yakni turut serta dalam ibadah dan ritual pemberian korban secara terus-menerus. ${ }^{14}$ Berbeda dengan orang fasik yang memakai lidah untuk menipu dan

11. Anderson, Psalms 1-72, 1:214.

12. Dahood, S.J., Psalms 1:1-50, 162.

13. Goldingay, Psalms 1-41, 1:384.

14. Tentang ibadah Israel lihat Robin Routledge, Old Testament Theology: A Thematic Approach (Downers Grove: IVP Academic, 2008); Walther Eichrodt, Theology of the Old Testament, vol. 1 (Philadelphia: Westminster, 1961), 98-177; William Dyrness, Themes in Old Testament Theology (Downers Grove: IVP, 1979), 143-59. 
sumpah serapah, pemazmur menggunakan lidahnya untuk menaikkan nyanyian syukur dan menyaksikan perbuatan Tuhan yang ajaib (ay. 7).

Pemazmur memberi kesaksian bagaimana ia hidup dalam kebenaran Tuhan ('ěmet) pada ayat 3. Kata benda 'ěmet diterjemahkan 'kebenaran' (TB-LAI, NIV) atau 'faithfulness' (RSV). Alfred Jepsen mengusulkan kata 'ĕmet diterjemahkan sebagai 'kebenaran'. ${ }^{15}$ Apakah artinya kebenaran Tuhan ('ěmet Tuhan)? Jepsen merumuskan kebenaran Tuhan sebagai berikut: "Yahweh is the God whose word and work one can place complete confidence" ${ }^{16}$ Kebenaran Tuhan merupakan karakter Allah. Manusia dapat mengandalkan perkataan dan perbuatan Allah dan melihatnya sebagai karakter Allah hal yang dapat dipercaya sepenuhnya. Dengan demikian manusia dapat bersandar dan bergantung total kepada Allah. Allah dapat diandalkannya dalam hidupnya.

Pemazmur menyatakan bahwa ia hidup dalam kebenaran Tuhan. Pernyataan pemazmur ini tidak hanya menegaskan ketergantungan mutlak kepada Allah sebagai Allah yang diandalkannya tetapi juga kehidupannya yakni perkataan dan perbuatannya dapat diandalkan oleh manusia yang berada di sekitarnya. Hidup dalam kebenaran Tuhan menunjuk kepada "the nature of the man who is said to be faithful to his neighbor, true in his

15. Alfred Jepsen, "'ĕmet," ed. oleh G. Johannes Botterweck dan Helmer Ringgren, Theological Dictionary of the Old Testament, 1 (Grand Rapids: Eerdmans, 1974), 323. LXX menerjemahkan 'ĕmet sebagai alētheia. 16. Jepsen, "'ĕmet,"., 313. 
speech, and reliable and constant in his action". ${ }^{17}$ Hidup dalam kebenaran Tuhan menggambarkan kehidupan pemazmur yang mencerminkan karakter Allah ('ěmet Tuhan) di tengah-tengah orang fasik yang adalah penipu, orang munafik, orang yang berbuat jahat.

Kebenaran dan kasih setia dalam kitab Mazmur sering bersandingan (Mzm. 25:10; 40:11, 12; 57:11; 86:15; 89:15; 108:5; $115: 1 ; 117: 2 ; 138: 2)$. Apakah kebenaran dan kasih setia adalah dua hal yang berbeda? Atau kebenaran merupakan wujud dari kasih setia? Seperti halnya kasih setia yang merujuk kepada karakter Allah, kebenaran juga menunjuk kepada karakter Allah. Kebenaran dan kasih setia menggambarkan dua aspek karakter Allah. Dua aspek karakter Allah ini menjadi dasar pemazmur untuk hidup dan berkarya di tengah-tengah pergaulannya dengan orang fasik.

Benturan kebenaran Tuhan dan kefasikan tak terhindarkan lagi. Itu sebabnya pemazmur memohon Allah menguji dan menyelidiki hidupnya. Pemazmur memohon agar Allah menguji dan menyelidiki batin dan hatinya bukan karena ia merasa tidak memiliki dosa atau tidak pernah berbuat dosa dan pelanggaran. Bukan dosa yang mendorong pemazmur untuk memohon pengujian dan penyelidikan dirinya. Mengapa pemazmur memohon pengujian? Pemurnian. Bagaimana penjelasannya?

Kata kerja šop̄ṭénî diterjemahkan TB-LAl sebagai 'berilah keadilan' (ay. 1). Kata kerja dasarnya yakni shāpat digunakan, misal, 
dalam Mazmur 7:9 'Tuhan mengadili (šop̄ṭềnî) bangsa-bangsa' untuk menggambarkan pemisahan orang benar tulus ikhlas dan orang fasik. Kata kerja berikutnya yang sejajar dengan kata kerja šop̣tếnî (berilah keadilan) adalah ujilah (bəhānēnî), cobalah (wənassếnî), selidikilah (ṣorôp $\bar{a}^{\mathrm{h}}$ ). Verba-verba itu digunakan untuk menguji, melebur, memurnikan emas, perak (Mzm. 12:7; 66:10; Ams. 17:3; 25:4). ${ }^{18}$ Emas, misalnya, dimurnikan dengan api.

Pemazmur hidup di tengah-tengah orang fasik, di tengahtengah api yang dapat menghanguskannya atau justru memurnikannya. Meski orang fasik membuat hidup pemazmur menderita, tetapi pemazmur melihat orang fasik berperan positif terhadap hidupnya. Kefasikan hidup menjadi latar kontras terhadap hidup pemazmur seperti benda putih diletakkan di tengah kanvas berwarna hitam. Itulah sebabnya pemazmur dengan penuh keyakinan memproklamirkan "aku hidup dalam kebenaran-Mu" (ay. 3). Tidak hanya itu. Hidup orang fasik laksana api memurnikan hidup pemazmur. Pemazmur membuka ratapannya dengan menyatakan "aku telah hidup dalam integritas" (ay. 1) kemudian menutupnya dengan pengakuan "aku ini hidup dalam integritas" (ay. 11). Integritas pemazmur diuji dengan api orang fasik. Hasilnya?

18. Anderson, Psalms 1-72, 1: 215, 475-76; Goldingay, Psalms 1-41, 1:382; Davidson, Vitality of Worship, 207; Frank-Lothar Hossfeld dan Erich Zenger, Psalms 2: A Commentary on Psalms 51-100, Hermeneia (Minneapolis: Fortress, 2005), 146; Craigie, Psalms 1-50, 225; Othmar Keel, The Symbolism of the Biblical World: Ancient Near Eastern Iconography and the Book of Psalms (Winona Lake: Eisenbrauns, 1997), 183-86. 
Pemazmur keluar dari api orang fasik dengan integritas yang lebih murni dari sebelumnya. Itulah sebabnya perubahan suasana teks (mood), seperti diperlihatkan di bawah, Mazmur 26 terlihat positif pergerakannya.

\section{Perasaan}

Benci (ay. 5)

Keberadaan dan interaksi pemazmur dengan orang fasik di seputarnya membuat penderitaan menjadi bagian hidupnya. Apa yang mampu dilakukannya terhadap mereka? Tidak ada. Relasi pemazmur dan orang fasik menimbulkan perasaan benci. Apa yang dibencinya? Pemazmur membenci perbuatan fasik. Kebencian lahir bukan karena persoalan konflik pribadi pemazmur dengan orang fasik. Kebencian pemazmur tertuju kepada perkumpulan orang yang berbuat jahat. Pemazmur tidak membenci orangnya, melainkan perbuatan orang fasik. Perbuatan orang fasik menyebabkan lahirnya keluhan pemazmur.

Arti benci dijelaskan pemazmur melalui kesejajaran dengan ungkapan-ungkapan tidak duduk (ay. 4, 5) dan tidak bergaul (ay. 4). Apa ini berarti pemazmur tidak memiliki relasi dengan orang fasik? Bila tidak memiliki relasi dengan orang fasik pemazmur tentu tidak mengalami masalah dalam hidupnya. Istilah 'tidak duduk' menyatakan relasi yang bersifat tidak terus-menerus. Pemazmur bergaul dengan orang fasik tetapi pergaulannya tidak permanen. 
Dengan perkataan lain, pemazmur berteman dengan orang fasik tetapi tidak bersahabat dengan mereka.

Cinta (ay. 8)

Perasaan lain yang muncul dalam diri pemazmur adalah cinta. Pemazmur cinta rumah kediaman Allah. Rumah Tuhan menunjuk kepada bait Allah di Yerusalem, tempat di mana umat Tuhan berkumpul dan beribadah menyembah Allah. Dalam persekutuan jemaat Tuhan, pemazmur menemukan kekuatan dalam menghadapi persoalan dan pergumulan hidup yang berada di tengah-tengah orang fasik. Bagi pemazmur rumah Tuhan menjadi tempat perlindungan dari serangan musuhnya. Mazmur 27:5 menulis "la melindungi aku dalam pondok-Nya pada waktu bahaya; la menyembunyikan aku dalam persembunyian di kemah-Nya".

Kehadiran Tuhan dalam jemaah (ay. 12) tidak didasarkan kepada perasaan pemazmur atau hal yang tidak pasti. Pemazmur tidak ragu kehadiran Allah dalam jemaat. Kepastian kehadiran Allah diungkapkannya melalui penggambaran keteguhan sepasti kaki berdiri di tanah rata.

\section{Allah}

Menyelidiki batin dan hati (ay. 2)

Pemazmur menyadari dan mengenal kemahatahuan Allah. Tidak ada yang tersembunyi di mata Allah. Semua terbuka di mata Allah. Pemazmur juga tidak dapat menyembunyikan apa pun dari 
Allah. Hanya Allah yang mengetahui batin dan hati manusia. Istilah batin dan hati secara harfiah dalam bahasa Ibrani 'selidikilah ginjalku dan hatiku'. Ginjal dipandang sebagai pusat perasaan, hati sebagai pusat pikiran. ${ }^{19}$ Pemazmur meratap kepada Allah untuk menyelidiki perasaan dan pikirannya. Hanya Allah yang mampu menembus perasaan dan pikiran manusia.

Kasih setia (ay. 3)

Kasih setia (hesed) Allah harus dipahami dalam terang perjanjian Allah dan manusia. Kesejajaran kasih dan perjanjian seperti tertera dalam Mazmur 89:29 dan 106:45 mendasari pemahaman keterikatan dan keterkaitan keduanya. Relasi manusia dan Allah bermula dan berjalan di dalam kasih setia Allah. Kasih setia dalam koridor perjanjian merupakan "the unceasing outworking of the Covenant relationship, the essence of which is summed up in 'I will be your God and you shall be my people' (Yer. 7:23)". ${ }^{20}$

Robin Routledge menjelaskan keterkaitan kasih setia dan perjanjian sebagai dua aspek yang saling melengkapi: ${ }^{21}$

1. Kasih setia berasal dari perjanjian (covenant) Allah dan umat-Nya. Perjanjian mengikat Allah untuk memperlihatkan kasih setia kepada umat termasuk di dalamnya kasih, kesetiaan kepada janjijanji-Nya, kebaikan, belas kasihan dan anugerah untuk tetap

19. Craigie, Psalms 1-50.

20. Anderson, Psalms 1-72, 1:215.

21. Routledge, Old Testament Theology, 109. 
bersama umat-Nya meski mereka berbuat dosa. Kasih setia menjadi dasar pengampunan dan pemulihan umat ketika berdosa terhadap Allah.

2. Kasih setia menjadi dasar kelanjutan relasi Allah dan umat meski umat tidak setia dengan beribadah menyembah dewa-dewi berhala. Kelangsungan relasi Allah dan umat didasarkan pada kasih setia-Nya yang menyediakan pemulihan dan janji akan pembaruan (Yer. 31:3; Hos. 2:18-20).

Ayat 3 memperlihatkan kesejajaran kasih setia dan kebenaran sebagai berikut.

3 mataku tertuju pada kasih setia-Mu, dan

aku hidup dalam kebenaran-Mu.

Kasih setia, seperti disebut sebelumnya, disandingkan dengan kebenaran. Kebenaran, dalam kaitan dengan kasih setia, memiliki dua sisi saling berkaitan dengan lainnya:

1. Kebenaran umat

Kebenaran berarti kehidupan umat yang mengerjakan semua tuntutan-tuntutan yang termaktub dalam ikatan perjanjian Allah dan manusia. Perjanjian menuntut umat untuk taat kepada hukum dan ketetapan Allah termasuk beribadah kepada-Nya dan mengasihi sesama manusia. Kebenaran adalah perbuatan dan perkataan umat seturut dengan tuntutan perjanjian Allah dan umat. 
2. Kebenaran Tuhan ('ěmet).

Allah mengikat diri-Nya dalam perjanjian dengan umat pilihanNya. Kebenaran Tuhan adalah tindakan dan perkataan sebagai wujud karakter-Nya sehingga umat menyerahkan dan memercayakan hidupnya secara mutlak ke dalam tangan Tuhan. Keterandalan Tuhan menjadi dasar relasi umat dan Allah yang sudah terikat dalam ikatan perjanjian.

Perbuatan yang ajaib (ay. 7)

Hidup pemazmur di tengah-tengah orang fasik membuka kesempatan baginya untuk mengalami perbuatan Allah yang ajaib. Pemazmur menggambarkan karya Allah dalam hidupnya sebagai perbuatan ajaib. Hidup dan berada di tengah orang fasik membawa pemazmur kepada suatu pengalaman baru tentang Allah. Pengalaman ini disaksikan pemazmur dengan pernyataan perbuatan Allah yang ajaib. Tidak hanya pengalaman pribadi dengan Allah yang dipandang pemazmur sebagai perbuatan ajaib, tetapi juga karya Allah terhadap bangsa Israel dalam sejarah. Perbuatan ajaib Allah terhadap bangsa Israel merujuk kepada pembebasan bangsa Israel dari perbudakan di Mesir.

Terhadap semua perbuatan ajaib yang dikerjakan Allah dalam diri pemazmur dan bangsa Israel, pemazmur memberi respons dalam bentuk nyanyian syukur (ay. 6). Isi nyanyian syukur adalah tentang perbuatan ajaib Tuhan yang telah dialaminya dengan hidup di tengah-tengah orang fasik. Pengalaman imannya berhadapan 
dengan orang fasik membawanya kepada integritas yang semakin dimurnikan. Bagi pemazmur pengalaman pemurnian integritas terjadi oleh karena perbuatan ajaib Tuhan dalam hidupnya. Inilah nyanyian syukur pemazmur. Secara spesifik pemazmur mengarahkan objek pujian syukurnya kepada kasih setia (hesed) dan kebenaran ('ĕmet) Tuhan. Pemazmur menyanyi syukur atas kebenaran Tuhan 'Akupun mau menyanyikan syukur bagi-Mu dengan gambus atas kesetiaan-Mu ('ěmet), ya Allahku' (Mzm. 71:22) dan juga menjadi kesaksian syukur kepada orang banyak 'kasih-Mu (hesed) dan kebenaran-Mu tidak kudiamkan kepada jemaah yang besar.' (Mzm. 40:11)

Rumah Kediaman (ay. 8)

Ungkapan rumah kediaman sejajar dengan ungkapan tempat kemuliaan bersemayam. Ungkapan rumah kediaman secara figuratif merujuk bait Allah di Yerusalem. Bait Allah adalah lambang kehadiran Allah di tengah-tengah umat-Nya. Kemuliaan Tuhan ditandai dengan kedatangan awan memenuhi rumah Tuhan (1Raj. 8:10-11). Kemuliaan Allah menurut Anderson adalah "divine holiness and power manifested". ${ }^{22}$ Kemuliaan Allah sebagai rujukan kepada kehadiran-Nya tampak dalam penglihatan nabi Yehezkiel bahwa Allah kembali masuk ke dalam bait Allah (Yeh. 43:4) setelah sebelumnya meninggalkan bait Allah (Yeh. 10:18; 11:23). Kehadiran Allah dan kemuliaan Allah dua sisi dari koin yang sama. Kehadiran

22. Anderson, Psalms 1-72, 1:217. 
Allah tampak melalui kemuliaan-Nya (Kel. 24:16-17). Dengan perkataan lain, kemuliaan Allah merupakan manisfestasi kehadiran Allah.

Bagi pemazmur berada di rumah kediaman Allah menjadi pilihan hidup satu-satunya. Pemazmur tidak ingin berada di tempat lain, kecuali berada di hadirat Allah. Lebih lugas pemazmur menyatakan bahwa berada di luar bait Allah adalah kematian (ay. 9). Orang berdosa dan penumpah darah tidak akan masuk ke dalam rumah kediaman Allah (Mzm. 5:5-7). Bila pemazmur memohon Allah tidak mencabut nyawa dan hidup tidak lain merupakan doa "for purification, while at same time affirming his integrity (ay. 4-5)". ${ }^{23}$

\section{Perubahan Suasana Teks (Mood)}

Pergerakan perubahan suasana teks Mazmur 26 dilukiskan sebagai suatu perubahan ratapan dan pujian sebagai berikut.

Ayat 1-2: ratapan

Ayat 3-8: pujian

Ayat 9-11: ratapan

Ayat 12: pujian

Pemazmur tidak berada dalam persekutuan atau perkumpulan orang jahat dan tetapi ia berada di dalam persekutuan jemaat (ay. 12). Ayat 12 merupakan nas pujian. Sebagai nas pujian ia mencerminkan bahwa pergumulan pemazmur hidup di tengahtengah orang fasik telah mendapat penyelesaian. Pergumulan

23. Craigie, Psalms 1-50, 226. 
pemazmur selesai bukan berarti pemazmur telah pindah keluar dari lingkungan orang fasik. Pemazmur mampu menaikkan pujian dalam ayat 12 oleh karena melalui dan di dalam pergumulannya, pemazmur telah mengalami perbuatan ajaib Tuhan. Integritasnya, sebagai akibatnya, telah mengalami pemurnian.

Keadaan perjalanan dan pergumulan rohani pemazmur di tengah orang fasik mulai dari ayat 1 hingga ayat 12 dapat digambarkan sebagai berikut:

\begin{tabular}{|l|l|l|l|l|l|l|l|l|l|l|l|}
1 & 2 & 3 & 4 & 5 & 6 & 7 & 8 & 9 & 10 & 11 & 12 \\
\hline & & & & & & & & & & & \\
\hline & & & & & & & & & & & \\
\hline & & & & & & & & & & & \\
\hline & & & & & & & & & & & \\
\hline & & & & & & & & & & & \\
\hline & & & & & & & & & & & \\
\hline & & & & & & & & & & & \\
\hline
\end{tabular}

Perubahan suasana teks menggambarkan keadaan pemazmur di tengah-tengah penderitaannya. Gambar di atas memperlihatkan suasana positif. Mengapa suasana positif? Meski perasaan benci timbul dalam diri pemazmur, tetapi perasaan benci itu tidak menguasai hati dan batinnya. Sebaliknya perasaan cintalah yang menguasai hati dan batinnya. Perasaan cinta ditemukan dan diperoleh pemazmur dalam persekutuan jemaat. Inilah yang membuat suasana positif dalam diri pemazmur.

Uraian di atas membawa kita kepada satu pemahaman bahwa pesan sentral Mazmur 26 adalah tentang pemurnian integritas 
pemazmur melalui keberadaan hidupnya di tengah-tengah orang fasik.

Federico Villanueva berpendapat bahwa pengkhotbah di Asia harus berhati-hati mengajarkan Mazmur 26. ${ }^{24}$ Mengapa? Menurut Villanueva Mazmur 26 merupakan penegasan pemazmur akan kebenaran dirinya ketika dituduh bersalah. Di Asia, papar Villanueva, orang tidak membicarakan kebenarannya di depan publik. Namun bila dituduh bersalah tidak salah bila menegaskan kebenaran dirinya seperti diajarkan Mazmur 26. Akan tetapi pesan sentral Mazmur 26 bukan itu. Berdasarkan pesan sentralnya, seperti dijelaskan di atas, Mazmur 26 justru harus disampaikan berulang-ulang kepada jemaat Kristen di Asia. Mengapa? Jemaat Kristen hidup di tengah-tengah masyarakat yang permisif, masyarakat yang memandang rendah integritas. Bagi jemaat Kristen di Indonesia yang hidup di tengahtengah bangsa dengan tingkat korupsi termasuk tinggi, integritas menjadi tantangan hebat. Jemaat Kristen Asia harus melihat keberadaan 'orang fasik' di sekeliling hidupnya sebagai 'api pemurnian' integritasnya.

\section{Renungan}

Pemazmur berada di tengah-tengah komunitas orang fasik. Penderitaan, tak terelakkan lagi, menjadi bagian hidupnya. Pemazmur membenci perbuatan jahat yang dikerjakan orang fasik. Perasaan benci muncul dalam diri pemazmur. Tidak hanya benci, 
tetapi muncul juga perasaan cinta. Dua bentuk perasaan (benci dan cinta) secara bertolak belakang bergulat dalam diri pemazmur. Penggambaran perubahan suasana teks tersebut di atas menampilkan suasana positif. Positif oleh karena tampak terlihat perasaan cinta lebih mendominasi. Tetapi ini tidak cukup. Ada dua alasan lain mengapa suasana teks terlihat positif.

Perbuatan jahat orang fasik mengepung hidup pemazmur. la tidak berdaya menghadapi mereka. Meski demikian keadaan tersebut justru membuka mata rohani pemazmur terhadap dua kekuatan dan pertolongannya. Pertama, persekutuan jemaat. Kedua, pemurnian hidup.

\section{Persekutuan Jemaat}

Tekanan orang fasik terhadap pemazmur demikian kuat menerpa hidupnya. Sesungguhnya pemazmur tidak kuat dan tidak sanggup menghadapi mereka. Ketidakberdayaan menghadapi perbuatan orang fasik menimbulkan perasaan benci dalam diri pemazmur. la benci orang fasik. Hanya ini yang mampu dilakukannya. Pemazmur tidak punya pilihan untuk keluar dari lingkungan orang fasik oleh karena ke mana pun ia pergi dan hidup, orang fasik tetap mengejarnya.

Meski demikian, ketidakberdayaan pemazmur menyadarkannya akan kekuatan persekutuan jemaat. Pemazmur mendapat kekuatan dan penghiburan dari dalam persekutuan jemaat. la tidak sendirian menghadapi persoalan dan pergumulan hidup. Setiap kali 
pemazmur pergi ke dalam persekutuan jemaat, hatinya diteguhkan untuk tidak tawar hati menghadapi beragam perbuatan orang fasik. Mengapa? Oleh karena Allah hadir di dalam dan melalui persekutuan jemaat. Persekutuan jemaat menjadi rumah kediaman Allah dan tempat kemuliaan-Nya bersemayam. Inilah sebabnya pemazmur cinta kepada persekutuan jemaat.

\section{Pemurnian Integritas}

Tidak hanya kekuatan dari persekutuan jemaat yang diperoleh pemazmur di saat kesulitan menghadapi orang fasik, pemazmur juga disadarkan akan peran positif keberadaan orang fasik terhadap hidupnya. Bagaimana penjelasannya?

Pemazmur berada dan hidup di tengah-tengah orang fasik. Tidak ada yang dapat dilakukannya untuk mengubah hidup mereka. Mereka banyak dan kuat seperti digambarkan ayat 3 (penipu, orang munafik, orang yang berbuat jahat, orang fasik). Kefasikan menjadi bagian hidup pemazmur. Keadaan ini menjadi sebab lahirnya ratapan pemazmur oleh karena persekutuannya yang intim dan erat dengan Tuhan Allah. Mata pemazmur tertuju kepada kasih setia Tuhan. Meski pemazmur tidak berdaya menghadapi perbuatan jahat orang fasik, pemazmur justru sadar bahwa keberadaannya di antara orang fasik menjadi sarana Allah untuk memurnikan hidupnya menjadi 
lebih berintegritas. Integritas pemazmur menjadi semakin mendapat pemurnian. ${ }^{25}$

Penderitaan orang Kristen bertujuan untuk semakin memurnikan pengenalan mereka kepada Allah. Hidup di tengah orang fasik menurut Mazmur 26 menjadi api pemurnian integritas pemazmur. Api pemurnian itu membawa pemazmur ke dalam pengalaman dan pengenalan akan perbuatan Allah yang ajaib.

Mazmur 26 memperlihatkan keadaan yang tidak diinginkan dalam hidup justru membawa kebaikan terhadap diri yang mengandalkan Tuhan. Pemazmur berada dalam keadaan persoalan atau pergumulan hidup yang tidak selesai dan terus-menerus menerpa bahkan menghunjam tajam hatinya. la tidak berdaya menyelesaikannya. Akan tetapi keadaan itu justru membawanya kepada dua pengalaman rohani yang luar biasa terhadap hidupnya. Persekutuan jemaat memberinya kekuatan menghadapi orang fasik.

Mazmur 26 menyingkapkan kekuatan persekutuan jemaat. Oleh karena itu, ketika kita menghadapi dan berada dalam pergumulan hidup yang berat, jangan sekali-kali meninggalkan persekutuan jemaat. Tanpa persekutuan jemaat kita tidak akan memiliki kekuatan menghadapinya. Tidak hanya itu. Pemazmur melihat keadaannya dengan mata rohani baru. Pemazmur tidak merasa perlu mengubah keadaan di mana ia berada oleh karena justru keadaan tersebut menjadi alat untuk memurnikan

25. Diskusi integritas lihat Jonathan Lamb, Integrity: Leading with God watching (Nottingham: IVP, 2006). 
integritasnya. Persoalan dan pergumulan yang tidak terselesaikan justru membawa kebaikan terhadap diri dan hidup pemazmur.

Kembali kepada pertanyaan di awal artikel, apa nasihat saudara bila mempunyai teman yang sedang menghadapi persoalan seperti dinyatakan di atas? Mengundurkan diri atau tetap bertahan? Berdasarkan penggalian Mazmur 26 terhadap teman itu diberi nasihat untuk tetap bertahan di kantornya. Mengapa? Keadaan itu justru merupakan kesempatan untuk memurnikan integritasnya melalui dan di dalam pekerjaannya. Pengalaman pemurnian integritas ini terjadi, seperti halnya pemazmur, oleh karena perbuatan ajaib Tuhan.

\section{Kepustakaan}

Anderson, A.A. The Book of Psalms: Psalms 1-72. Vol. 1. New Century Bible Commentary. Grand Rapids: Eerdmans, 1972.

Barus, Armand. Mengenal Tuhan Melalui Penderitaan. Jakarta: Scripture Union Indonesia, 2016.

- "Menghadapi Kebohongan: Penelitian Puitis Mazmur 4". Jurnal Amanat Agung 14, no. 1 (Juni 2018): 1-24.

- "Sembuhkanlah Aku: Penelitian Puitis Mazmur 6". Jurnal Amanat Agung 12, no. 2 (Desember 2016): 175-206.

Craigie, Peter C. Psalms 1-50. Word Biblical Commentary 19. Dallas: Word Books, 1983.

Dahood, S.J., Mitchell. Psalms I: 1-50: Introduction, Translation, and Notes. The Anchor Yale Bible 16. New Haven: Yale University Press, 1965.

Davidson, Robert. The Vitality of Worship: A Commentary on the Book of Psalms. Grand Rapids: Eerdmans, 1998. 
Dyrness, William. Themes in Old Testament Theology. Downers Grove: IVP, 1979.

Eichrodt, Walther. Theology of the Old Testament. Vol. 1. Philadelphia: Westminster, 1961.

Goldingay, John. Psalms 1-41. Vol. 1. Baker Commentary on the Old Testament Wisdom and Psalms. Grand Rapids: Baker Academic, 2006.

Hossfeld, Frank-Lothar, dan Erich Zenger. Psalms 2: A Commentary on Psalms 51-100. Hermeneia. Minneapolis: Fortress, 2005.

Jepsen, Alfred. "'ěmet." Disunting oleh G. Johannes Botterweck dan Helmer Ringgren. Theological Dictionary of the Old Testament. 1. Grand Rapids: Eerdmans, 1974.

Keel, Othmar. The Symbolism of the Biblical World: Ancient Near Eastern Iconography and the Book of Psalms. Winona Lake: Eisenbrauns, 1997.

Kidner, Derek. Psalms 1-72: An Introduction and Commentary on Books I and II of the Psalms. The Tyndale Old Testament Commentaries. Downers Grove: IVP, 1973.

Lamb, Jonathan. Integrity: Leading with God watching. Nottingham: IVP, 2006.

Routledge, Robin. Old Testament Theology: A Thematic Approach. Downers Grove: IVP Academic, 2008.

Villanueva, Federico G. Psalms 1-72: A Pastoral and Contextual Commentary. Asia Bible Commentary Series. Carlisle: Langham Global Library, 2016.

Weiser, Artur. The Psalms: A Commentary. The Old Testament Library. Philadelphia: Westminster, 1962. 